The Malaysian Journal of Social Administration, 10: 87-114.

\title{
FAMILY ECOLOGY AND ADOLESCENTS PREMATURE PREGNANCIES: MULTIPLE CASE STUDIES OF MALAYSIA
}

Siti Hajar Abu Bakar Ah (Ph.D)

Associate Professor, Department of Social Administration and Justice, University of Malaya, Kuala Lumpur

shajar@um.edu.my)

\section{Noralina Omar}

Ph.D candidate, Department of Social Administration and Justice, University of Malaya, Kuala Lumpur (nora2374@yahoo.com)

\section{Siti Balqis Mohd Azam}

M.A student, Department of Social Administration and Justice, University of Malaya, Kuala Lumpur (balqis_azam@yahoo.com)

\begin{abstract}
Brofenbrenner's theory on Human Ecology postulates that a human interaction with their environment produces certain types of behaviours. This paper examines the effect of social ecology, in particular the family ecology, on girls' sexual misconduct which later contributed to them being pregnant out of wedlock. The data were from two qualitative studies that involved 15 juvenile girls, who were under the care of two state institutions - the Taman Seri Puteri and, the Henry Gurney School. Findings from both studies supported the theory's premise, which is, unfavourable conditions of family environment is detrimental to its members behaviours, in particular children. The studies found that family ecology, such as poverty, parent's abandonment and violence in the family, depressing parent's marital relationship, broken family, and ineffective parents-child communication lead to child involvement in premature sexual behaviour, and later bruising their development when the misconduct contributed to their pregnancy. The findings have significant implication on the National Child Protection Policy. The existing policy needs to take into account the importance of a family-based intervention program to response to the social ill.
\end{abstract}

Keywords: Family ecology, out of wedlock pregnancy, premature pregnancy, adolescent girls, family-based intervention programs 


\section{INTRODUCTION}

Out of wedlock pregnancy among adolescent girls is an alarming social epidemic in Malaysia. In 2011, there were 4222 cases of out of wedlock pregnancies among the 10 to 19 years old girls, nationwide (Malaysia, Ministry of Health in Doshi-Gandhi, 2013). Prior to 2011, there were only 111 reported cases (Social Welfare Department of Malaysia, 2010). It is worrying to see the 38 times increment, as it reflects the severity of the problem.

Pregnant out of wedlock left behind critical impact to the lives of the involved adolescents, due to their immaturity. First and foremost, it disturbs their natural development. Studies never fail to prove that most of the pregnant adolescent failed to finish their schooling, being a single mother at a very young age, involve with insecure, low paid jobs, involve with immoral conducts, end up to raise their kids in high risk communities, and are prone to various diseases due to bad health conditions. Criminal justice system for children in most countries provides legal measures to remedy social problem of this type. Criminal justice system and child welfare services of most countries provide measures for restoration for delinquent children. For this case, the juveniles are placed under the care of the state, and institutionalised for rehabilitation, protection, and corrected.

No parents want their child to be detached from them, or want to see their children being detained and rehabilitated in any rehabilitation or corrections institution as these institutions are regularly attached with negative labels. Thus, to prevent this from happening, we must curb the problem. The initial move is to understand the problem. For the context of this study, identifying factors that lead to adolescents out of wedlock pregnancies is the first step to understand the issue. Many factors contribute to adolescent premature pregnancy; such as consensus sexual intercourse, involvement in free sex or premature sex activities with peers, sex abused, sex manipulation, incest, and resulted from rape incidents. Exhaustive understanding about the antecedent factors is pertinent to the development of effective preventative intervention to the problem. 
Family can protect their adolescent girls from being pregnant out of wedlock if community members are genuinely trying to help by intervening effectively to the identified antecedent factors. Speaking of prevention, direct prevention controls which proactively address opportunities for crime (Gilling, 1997, p. 3) is always the best measure. It is contrary to the corrective and punitive prevention, which seeks to address the cause of crime, and deter the crime behaviours through the force of the criminal justice system (Gilling, 1997, p. 4). Or, borrowing the approach of medical epidemiology, the prevention efforts are categorised to three typologies; primary, secondary and tertiary prevention. Brantingham and Faust (1976, p. 292) regarded primary prevention as the ideal objective as they seek to secure the elimination of criminogenic conditions in society, thus being truly proactive, while tertiary interventions are the least satisfactory, but conversely constitute the main business of the criminal justice system and its correctional interventions into offenders' lives.

This paper examines the relationship between family ecology and teenagers' involvement in sexual activities. The main purpose of the paper is to identify antecedent factors in family ecology that cause teenage girl's involvement in premature sexual activities, and later contribute to their pregnancies. The ultimate outcome is to propose a primary prevention program that is family-based that could response effectively to the problem of out of wedlock pregnancies among teenagers in Malaysia.

\section{LITERATURE REVIEW AND RELEVANT RESEARCH}

\section{Theoretical framework}

According to Bronfenbrenner's theory of Human Ecology, behaviours are the product of individual's communication with his/her social environment. Human interaction with their environment produces certain types of behaviours. Hypothetically, inhospitable environment will produce depraved behaviours.

Human ecology comprises of four level of systems; microsystem, mesosystem, exosystem, and macrosystem (Brofenbrenner, 1986). The microsystem 
is the direct ecology person has in his/her lives. It includes a group of social agents, such as family, friends, classmates, teachers, neighbours and other people who have a direct contact or social interactions with an individual. The mesosystem involves the relationships between the microsystems in individual's life. A child family experience is related to his/her school experience. Thus, the child may have a low chance of developing positive attitude towards his teachers if he/she is neglected by his/her parents. Then, the exosystem is a system in which the person plays no role in the construction of experiences, but these experiences have a direct impact on the microsystems the person is part of (Brofenbrenner, 1986). For instances, if a child is more attached to his father, there may be a conflict between the mother and the child's social relationship if the father passed away. Finally, the macrosystem is the cultural contexts that involve the socioeconomic status of the individual. Each of the environmental system has a different influence on human development.

For the purpose of discussion, this paper concentrates only on the family level at the microsystem. Family ecology consist of group of variables, such as family socio-demographic, parenting style, parental control and monitoring towards children behaviour and activities, parent-child communication, parental support and family structure.

\section{Family ecology and adolescents out of wedlock pregnancies}

\section{Economically-physically challenged family environment}

Numerous literatures and researches prove that most pregnant out of wedlock adolescents come from poor families. Young et al., (2004), for instances, in their study among 25,000 American teenagers found that teenagers who experience external poverty; insufficient family monthly income, impoverished, parents with low educational attainment and performance background, parents employment in low status job and income, and have limited resources are at a greater risk being involved in premature sexual activities and pregnant out of wedlock.

Katerndahl et al., (2005) confirmed that a family poverty is the main risk factor for adolescent's premature pregnancy. They studied how the layouts of a crowded home contribute to premature pregnancy among impoverished adolescents. Poverty 
forced adolescents to share rooms with their male siblings or family members; who in most cases provide an opportunity for incest or rape.

Miller, Benson and Galbraith (2006) also found that adolescents that come from low-income family environment are at the greatest risk of involving in premature sex activities and being pregnant out of wedlock. Compare to the adolescents from good income background, they are more likely to be sexually active and less likely to use contraceptives due to their ignorance. They are not only are at-risk for premature pregnancy; but also are at-risk for infection of dangerous sexually transmitted diseases.

Adolescents whose parents are with good educational background and achievement typically involved with jobs that provide satisfactory earnings to maintain their family needs. Families with high and steady monthly income serve as a protective factor against teenage pregnancy out of wedlock. Studies by Tomall (1999), Williams and Vinnex (1999), and Hogan and Kitagawa (1999) revealed that family monthly income and adolescent premature pregnancy has a distinctive linear relationship. The lowest the family monthly income, the highest are the rate of teenage pregnancy. Gordon (1996), based on his longitudinal studies about teenage pregnancy in the United States of America concluded that the relationship between family poverty and teenage pregnancy is so strong. The powerful association between the two urged Gordon to assume that teenage pregnancy in the U.S could not be abolished entirely if existing intervention programmes and anti-poverty policies of the country failed to response to the problem of family poverty, at the foremost.

\section{Disrupt family structure}

Majority of adolescent girls who involved with sexual offences came from disturbed family structure, in particular single parent family. Miller et al., (2006), for example, found that most pregnant teenage girls come from single structure family that are headed by a mother. Matriarchal incapacity impaired the mother's competency to control and supervise their children. Compare to a family with a father and mother, single family that are headed either by mother or father are less capable to supervise, 
control and monitor their children whereabouts and behaviours. Most single father or mother need to spend most of their times at the workplace to earn a suffice salary to support their family. Absent of supervision and control from parents provides an opportunity for the children to be involved with antisocial behaviours, including sexual activities that may contribute to their pregnancy. Parent's unavailability to allocate quality time to communicate and supervise their children forced children to spend their time with strangers or peer groups to gain knowledge or information about sex and this situation put them in greater danger for sexual exploitation.

Subsequently, Burns (2008) claimed that teenage girls from single-mother family look for a father figure to guide their lives, which may lead to their involvement with adult men that they perceived, possess fatherly physiognomies. These girls seek attention from adult men through sex intimacy. When the girls fall for irresponsible and immoral men, they are at the highest potential to be sexually manipulated which later contributes to their premature pregnancy. On the other hand, absent of father in a single mother family contribute to the deficit male authority persona and male role-model among teenage boys. The important impact of these deficiencies on the boy's interpersonal development is they do not have significant resource to socialise them about responsibilities associated to gender and masculine personalities that do not need to be proven by sexual behaviours.

Seem to be present everywhere, formation of single family is frequently from parents' divorce. Quinlivan et al., (2004) found that most teenage pregnant girls involved in their study came from single structure family resulted from parents' divorce. Wellings et al., (1999) also found that majority of Briton pregnant adolescents involved in their study came from single structure family that was caused by their parents' divorce. Blake and Bentov (2001) came across the same situation in their studies about premature pregnancy among teenage girls in the States.

For the local context, Siti Hajar and Abd. Hadi (2009) in their study about antisocial behaviours among at-risk children also found similar findings as their counterparts in the west. They found that children from single family structure due to divorce were at a greater risk being involved with premature sex; compared to the children that came from single family structure due to deceased of either father or 
mother. Frustration felt by most children from single family structure due to divorce aggravate them to be rebellious. One of the channels is to spend their time outside their homes, mingling with antisocial peers, involving with disruptive activities, including premature sexual activities.

\section{Violence in the family}

Physical abuse, sex abuse, and incest that occur in the family setting are main reasons for adolescent premature pregnancy. Miller et al., (2006) found that most of the pregnant teens had experienced either physical or sexual abuse. The traumatic experiences trigger them to commingling with corrupt peers, whom later provide avenue for the teens to involve with sex activities that may result to their premature pregnancy. Miller et al., also found that few of the pregnant teens that involved in their study claimed that the traumatic experience of being rape and incest rouse their obsession to involve in free sex activities with either their peers or male adults. They claimed that their endeavours were consensus, as a way to express their selffrustration and self-anger, and even some of them claimed that they lost their conscience about being moral and immoral. Some of them also claimed being introduced to sex at an early age make them addicted to the act, which provoke them to be rampantly involved in uninhibited and unprotected sex activities. Miller et al. concluded that the chain of events set them at the imminent risks being pregnant prematurely.

Most researches about unwanted pregnancy among adolescents also had established specific characteristics of family environment where the incidents of sexual abuse occurred. Cervera (1994), for instances, discovered that adolescents who had experienced physical and sexual abuse and then pregnant lived in a home where incest, suicide, substance abuse and another form of criminal activities occurred among the family members. As the escapism, the traumatic experiences pushed them to problematic behaviour, and once associated with the behaviour they are at the highest risk of being pregnant.

Francisco et al., (2007) compared studies about teenage premature pregnancy across the United States, England, Canada and Sweden to find a relationship between 
sexual abuses experienced by the teenage girls while they were young, with their premature pregnancy. The comparison studies provide clear empirical evidences to prove that adolescent girls that experienced sex abuse while they were kids are at the highest risk being involved with sexual activities at their teenage, and later contribute to their premature pregnancy.

Martin et al., (2010) conducted a survey on a group of pregnant teenage girls that involved with several types of problem behaviours. Most of them were victims of family abused; physically and sexually. Most unwanted pregnancy amongst the girls were the result of being sexually assaulted or abused by their family members their fathers, stepfathers, siblings, uncles or grandfathers. Uncontrollable physical abuse can spread to sexual abuse such as incest and rape. The incidents set the teenage girls who grew up in that vicious family environment at a higher risk being pregnant. Martin et al. also observed that most of the teens that had experience of sex abused display several pattern of destructive behaviours and emotional symptoms such as anxiety, depression, reduced self-esteem, absent of self-righteous, sleep disturbance and somatic complaints at different level of severity. They also involved with certain behaviour problems such as delinquency, substance abuse, and premarital sexual activities.

On a par, Steel and Herlizt (2005) conducted a study among 2810 teenagers in Sweden. They found that there was clear association between the teenagers involvement in sex activities at their young age, infected with venereal diseases at the early age, repeated unwanted pregnancies at their young age, and were at extreme tendency to participate in group and unprotected sex activities, with their experience of being victims of family maltreatment when they were young.

Again, Quinlivan et al., (2004) found that teens who had experiences growing up in a family that was full with violence behaviour, in particular witnessed their mother being abused by the father is a factor that strongly influences the teenage girl's premature pregnancy. Most of out of wedlock teenage girls in Victoria, Australia, who involved in the study, reported that they had experienced violence in their families while they were toddlers or children. Witnessing the violence relationship between their parents caused them to develop a hostile family 
environment, since young. The violence environment scares the child away. Terrified with their abusive parents makes it difficult for them to communicate with their parents, and thus it sever their relationship with their parents. To prevent witnessing their father violence's on their mothers, most of them chose to spend their time outside the homes, or run away from their homes. During the association with bad influences peers, they are exposing to different negatives influences, such as drug abuse, alcoholic, pornography, and free sex activities. Most of the runaway teens are prone to involve in the prostitution activities as an easy means to ends meet. All these were important antecedent factors to their premature and unwanted pregnancy.

\section{Damaging parenting style}

Five dimensions of parenting style that have a strong influence on child sexual behaviours are parents-child relationship, parents' supervision style, parents' sex socialization practices, parents' social behaviour role-model, and parents' values about sex. Studies confirmed that conflict child-parents interaction/relation, submissive parenting style, lacking parental support, control and supervision and parents' permissive values toward sexual behaviours are key influences in teenage girls out of wedlock pregnancy.

Children who grew up in a household where parents practice the authoritative style of parenting; which are rigid in term of child discipline, yet at the same time allow the child to make own decision about their lives are reported to produce positive behaviour outcome among children, and can protect the children from negative behaviour such as unprotected sex and premature pregnancy. The finding is contrary to the authoritarian parenting style. In this particular type of parenting, parents are likely to embody rigid rules and regulation about child socialization, harsh punishment system, punitive physical punishment, and intolerance behaviours towards the child. Most pregnant teens are the product of this kind of parenting (Velez-Pastrana, 2005; Ballantine, 2001).

Tucker, Perreira and Halpern (2011) studied three effects of parenting strategies; parent's affection and guidance, parent's communication and expectations, and parent's role-model, on premature pregnancy among 10,932 teens 
in North Carolina, U.S.A. They found that teens that came from a family that parents are authoritative provide a conducive support, and explicit control and supervision were less likely to be involved with premature sexual activities and premature pregnancy. The outstanding dissimilarity was seen among teens that came from the authoritarian and laissez faire parenting styles. Most of the pregnant teenage girls who involved in the study came from this kind of parenting. The study concluded that parents who are warm and affectionate, supportive, assertive discipline towards child behaviour and positive role-model are proficient to diminish child involvement in disruptive behaviour, including unprotected sex activities and premature pregnancy.

Benson (2004) analysed parents-child communication and adolescents' sexual behaviour. He found that poor communication or communication breakdown between family members, especially between child and parents; unstable family relationship, conflict family environment and negative style of parenting are significant contributing factors to pregnancy among adolescents. Most pregnant adolescents in the study had uncertain or hostile relationship with their mothers, the parental dyad, aloof relationship and poor communication between siblings.

Parents, exclusive mothers, are primary sexual educators and sex socialization agent for children (Hutchinson \& Cecedbaum, 2011). Compare to a father, a mother is the principal communication consultant related to issue of sex and sexuality to a child. Mothers have persuasive power in the socialization of sex behaviour in children and the creation and development of positive child belief and confidence about sex and sexuality (Guilamo-Ramos et al., 2008; Dilorio et al., 2007). Parentschild communication about issue related to sex is vital for the process of constructing a child's mind set and perceptions about sexuality; as well as in governing the child behaviour related to sex.

Commendador (2011), for instances, studied the relationship between parenting practices and teens decisions in using contraceptives. 112 Hawaiian adolescent girls in the age range of 14 to 17 years old, from various ethnicities involved in the study. Commendatory discovered that the parenting style adopted by her respondents 
mothers function as preventative and control agent to teens pregnancy. Mothers' parenting style plays an important role in influencing the teen's decision to use contraceptive, and to delay their involvement in premature sex activities to their adulthood. This study also established the fact that mothers; compared to fathers, are the primary family communication medium, in particular for daughters to discuss issues related to sex and sexuality. Most of the teen's girls in the study reported that they relied on their mothers for information, counselling and guidance related to sex behaviours and their reproductive assets. Teen's girl who had a conducive communication, open interaction, and instructive discussion with their mothers about sex and sexuality issues were perceptive in making decisions about their sex behaviours.

Regarding parents' values about sex and sexuality, few studies had confirmed that effective parents-child communication about sex and sexuality depends on parents' attitude towards sex and sexuality. Parents with conservative sex values and attitudes are more capable to protect and prevent their children from involving in premature sex and premature pregnancy. In their study in Brazil, Hoga, Borges and Alvarez (2009) found that conservative values and socio-cultural function as "stumbling block" for families to control their teenage child, in particular their teens girls from involving in free sex activities and out of wedlock pregnancy. Local values and social norm that viewed pregnant out of wedlock as embarrassment and disgraceful to the family dignity, somehow rather render family responsibilities to supervise their daughters from any immoral behaviour that may cause out of wedlock pregnancy. On the other hand, the study found that parents that lacked positive rolemodel about sex and sexuality, conservative to talk about sex, and hold a permissive attitude about sex and sexuality send their children away to find information about sex and sexuality from others irresponsible adult, peers, or information channels. Potentiality for the teens to receive wrong and harmful information and knowledge about sex and sexuality from those mediums were imminent, which in turn, most of them ended up being involve in premature sexual activities and pregnant. 


\section{Promiscuity family}

Adolescent girls whose mothers and siblings, in preference their elder sisters, involved with premature sexual activities and pregnant out of wedlock, are at the greatest risk of involving in premature sex activities or being pregnant out of wedlock. Hutchinson et al., (2012), studied sexual behaviour among 46 Jamaican teens girl (14-18 years old), and 30 mothers or female caregivers to the teens. They uncovered that mothers or female caregivers with negative sex behaviour role-model, such as promiscuity, sex with many partners, accepting unprotected sex as healthy behaviour, and encourage their daughters to involve with prosperous adult male, were at a high risk to coaching their teen daughters to involve in premature sex and premature pregnancy. Teen girls who grew up with this type of role-model are at-risk for out of wedlock pregnancy.

\section{Antisocial family}

Studies had proved that adolescents who involved with unprotected premature sex activities which resulted to premature pregnancy came from a family that parents, or either mother or father, involved with numerous crime activities, such as drug abused, crime related to drugs, prostitution, gangsters, gambling and alcoholic. Nash, McQueens and Bray (2005) discovered that antisocial or criminal parents furnish a learning space for their children to learn and follow in the footsteps. Nash and his coresearchers found that most delinquent teens in their study, who involved with premature sex activities, live with parents or one of the parents who are a drug addict, convict, pimp, sex workers, and involved with gambling and prostitution rings or cartels.

Explanation in this section gives us a clear picture about ways in which family ecology predispose adolescent girl's premature sex behaviours, which later contributed to their premature pregnancy. The antecedents are complex and interrelated. None of the factors are either dominant or insubstantial in influencing adolescents' sexual behaviours. In order to understand how family ecology affecting teenagers sexual behaviour, all the factors need to be mutually analysed. 


\section{METHODOLOGY}

In the last quarter of 2012, two qualitative studies were conducted to understand factors contributing to adolescent premature and out of wedlock pregnancies. Below are explanations about the method used for the studies.

\section{Research design}

The study is explanatory in nature. Thus, qualitative design within the case study tradition was planned to collect in-depth data about family factors that affecting adolescent involvement in premature sex activities, and premature pregnancy. The case study adopted the multiple case study method, in which the same set of questions were replicate to the subject of the inquiry, that was a group of pregnant teenage girls who were enrolled into two public social rehabilitation and protection institution, in a selected boundaries. One was Probation Hostels for wayward girls, and the other one was Approved School for girls who involved with crime activities that are punishable.

\section{Population and sample}

The population of the study was adolescent girls (14 to 18 years old) who are pregnant out of wedlock. However, for a sample, we decided purposively to focus on pregnant adolescent girls who were referred to the Social Welfare Department of Malaysia, and Prison Department of Malaysia.

In Malaysia, Section 17 of the Child Act of 2001 stipulated that it is misconduct and assaulted to the minor when she is pregnant; even if it results from consensus sexual activities. The assumption is the child has been, or there is a substantial risk that she will be sexually abused, the parents or guardian of the child is unfit, or has neglected to exercise proper supervision and control over the child and the child is falling into bad association. In this manner, the child is assumed in need of care and protection. As a protective measure, Section 41 of the Act stated that the child need to be removed to a "safe place" such as the Social Welfare 
Department's probation hostels for series of rehabilitation programs. On another provision, a child can be sent to the Henry Gurney Schools (for girls) once she is found guilty of any offence punishable with imprisonment.

Girls who were referred to the Social Welfare Department of Malaysia were those that assumed in need of care and protection. Nine girls who were residents of Taman Seri Puteri, Cheras Kuala Lumpur (Garden of the Princess) voluntarily represented a sample under this category. Whereas, the second sample were adolescent girls who had been arrested and convicted with criminal offences for baby dumping and attempted murder. They were detained in the Approved School - Henry Gurney School (for girls), in Muar, Johor. Six girls under this category involved in the study.

\section{Sampling technique}

In term of method of sampling, two types of sampling were utilised to get the sample of the study. The first technique is the purposive sampling. This method was used to decide the sample type; that was adolescent girls who are premature pregnant and out of wedlock and were referred to the care of the state for rehabilitation, protection, and punishment. The method also was used to select types of child institution involved. The team, decided to select two agencies under the Rehabilitation and Protection Services; the Probation Hostels and Approved School.

The second method is the convenient sampling. The technique was used to select location of the study. We decided to conduct the research in two locations; Taman Seri Puteri, Cheras, Kuala Lumpur, and Henry Gurney School, Telok Mas, Malacca. Then, extreme or deviant case sampling, in which use to explain or describe problematic case or to highlight particular cases that are "troublesome" in nature (Creswell, 2008) was used to select a sample and respondents of the studies. 


\section{Data gathering technique}

In-depth interviewed; flexible guided by an interview protocol were carried out to the selected fifteen adolescent girls (anonymous names were given to them to protect their identity).

\section{Procedure}

The probation officer selected the detainees with inclusion criteria that had been set up prior to the fieldwork. The inclusion criteria were premature pregnant adolescent girls who are in the probation institution for at least 6 months. Even though, the Probation Officer gave their names, their consent to participate in the study were granted as the researchers want to ensure that their participation were on a voluntary basis. In the first meeting, the researcher sensibly explained to them about the purpose of the study; processes involve in the study, questions involve, and also about reporting procedure. Explanation about assurance to protect their identities was precise. They can decide to withdraw from the study at any time of their preference if they were uncomfortable with the subject. All participants signed a document of agreement to participate in the study.

\section{Instrument and data collection}

The interview protocol consists of four general questions. The first question was about the respondents' family socio-demographic profiles (i.e., what is your parent's employment? how many siblings? Before enrolled into this institution, do you live with your family? ). The second question was about causes of their premature pregnancy (i.e., when did you know that you are pregnant? May you tell us how it happen?). The third question was related to their partner's information (i.e., who is/are responsible for the pregnancy?). The final question surrounded around their pregnancy (i.e., How do you feel with the pregnancy? What are you going to do with your pregnancy and your baby?). With the respondents' concern, we recorded all the interviews. This paper only displays findings for question number one, and part of 
findings for question number two. Findings were descriptively analysed using manual coding. Meanings were grouped and discussed in various themes.

\section{FINDINGS}

With all due respect, findings from these two studies resembling findings from most of the previous studies mentioned in the Literature review section.

\section{Adolescents from low-income family background}

Almost all (86.7 per cent) of the respondents in these studies came from low-income household. Out of 15, only two respondents (13.3 per cent) reported that their father had permanent jobs with a steady income. Aminah's father work as firemen, while Ayu's father work as a factory supervisor. When asked about their father wages, both of them considered the salary as just enough to end meet. For the rest of the respondents, their father involves in this kind of job - self-employed, security guard, technician, lorry driver, a delivery man, mechanic, and unreliable seasonal cheap labour (i.e., carpenter) that only provide low and insufficient earnings.

Most mothers of the respondents were full-time housewives. Only two respondents (Tehah and Aya) stated that their mothers work as a clerk. Meanwhile, for three respondents who grew up with their grandmother (i.e., Tina, Siti and Ida), none of the members of the household engaged in any form of salaried employments. All the three grandmothers were senile and sick, and were incapable to perform any work.

There was only one convincing verbatim about ways in which experience of growing up in a poor family contribute to the respondents involvement in premature sex activities, which later lead to the premature pregnancy. One of the respondents told the researcher that her family poverty forced her to quit her schooling. She later worked as a waitress at her step-mother's food stall. The job gave her a lot of opportunities to meet few men. She involved with them, and eventually was impregnated by one of her acquaintances. 


\section{Alternative family's structure}

Only three respondents (20 per cent) - Sha, Nur and Tehah grew up in an intact family; with their parents and siblings. Twelve respondents ( 80 per cent) came from alternative family structure. From the composition, two respondents (16.7 per cent) grew up in a single parent family's structure that was headed by grandmothers. Both of them were left to their grandmother since babies due to their parents break up. The other eight respondents (66.6 per cent) grew up in blended family's structure, headed by step-parents, step-fathers or step-mothers. The other two respondents (16.7 per cent) grew up with their adopted families since babies. Examples of verbatim for their family structure are in Table 1 . It is very obvious that detached families with features, such as divorced parents, unknown father or mother, step-family's structure, and either father or mother was biology unrelated to the respondent is risky family factors to adolescent girls out of wedlock premature pregnancy.

Table 1: Selected verbatim related to respondents' family structure

\begin{tabular}{|c|c|}
\hline Respondents & Verbatim \\
\hline Aminah & $\begin{array}{l}\text { "....my father divorced my mother. I live with my father and my step-mother" } \\
\text { (Aminah, HG, P1/9 October 2012: } 9.00 \text { a.m) }\end{array}$ \\
\hline Siti & $\begin{array}{l}\text { "...my mother is still alive, but not my father. I live with my late father mother } \\
\text { (grandmother)" (Siti, HG, P1/9 October 2012: } 10.15 \text { a.m) }\end{array}$ \\
\hline Tina & $\begin{array}{l}\text { "I am an adopted child. I do not know my real parents. Up to now, I do not know } \\
\text { anything about them. I live with my foster parents" (Tina, HG, P1/9 October 2012: } \\
2.00 \text { p.m) }\end{array}$ \\
\hline Eira & $\begin{array}{l}\text { "My mother? My mum separated from my father long time ago. Now, I have a } \\
\text { step-father"(Eira, TSP, P1/9 January 2013: } 10.58 \text { a.m) }\end{array}$ \\
\hline
\end{tabular}

Parents' remarriage set off distress and angriness in children. Eira, for instance, told us that her mother second married attribute to substantial problems into her lives. She could not and will never accept her mother second marriage. She did not like her step-father. Her relationship with her mother was interrupt and distant since then. Obviously, Eira involved with antisocial friends to show her protest and rebel. She became aggressive, naughty, and beyond control child. She started to skip school, joined her illegal biker's male peer's activities, associate with friend who 
associated with drug abuse, and involve with premature and unprotected sex with numerous partners. Eira told the researcher:

"My mother promises me that when I get out from this institution she will ask my step-father to divorce her. She knew that I did not happy with her marriage, and her marriage is the reason I behaved badly."

(Eira, TSP, P1/ 9 January 2013/10.58 am)

\section{Immoral and criminal parents}

Two of the respondents come from a household in which one of the parents; especially the father involved in vice behaviour or activities. In the case of Siti, her father was a habitual drug addict. He loved to share his needle with his friends, whom most were also drug addicts. The habit caused him with HIV infection, which few years later took his life. When was asked about her mother, she just kept quiet. It took us few meeting to get Siti to talk about her mother. According to Siti, her mother engages in some job related to the sex industry. Since young, she witnessed her mother corrupt behaviour. Her mother involved with countless men to sustenance the family lives.

Mira's father is a criminal. He involves in crime activities such as drug trafficking, illegal firearms dealer, boss one the organised gangster group in Kuala Lumpur, and also a pimp. According to Mira:

\footnotetext{
"My father......he is a gangster..... a gangster in KL.... He smuggles drugs, controls the prostitution rings in KL, distribute and sell illegal firearms, and lead one of the organised gangs in the town. I associated with premature sex activities because of him. He loves to bring home his friends. One of his friends is handsome. I like him so much. He lured me until I was so obsessed with him. I did the intercourses many times with him. Then, one day, got pregnant"
}

(Mira, HG, P1/9 Oktober 2012: 4.00 p.m) 


\section{Problematic and conflict child-parents relationship}

All respondents (100 per cent) stated that they did not have either good or pleasant relationship with their parents, mother or fathers. 14 of them (93.3 per cent) further explained that they had difficulties to communicate with either their parents or one of the parents. Compare to mothers, majority of them reported that they did not have a good relationship with their fathers. Sha, Bai, Asma, Tehah, Aya and Eira, for example, expressed that they hate their fathers due to their bad behaviours, such as hot tempered, hostile, aggressive, autocratic, deceitful, irresponsible towards their families, failed to perform their roles or responsibilities as either the husband or father, abusive, double standards, and selfish (in the sense that did not spend times with their children due to either busy with their jobs or love to spent times with friends). Examples of verbatim related to the question are in Table 2.

Table 2: Selected verbatim related to respondents' relationship with their parents

\begin{tabular}{|c|c|}
\hline Respondent & Verbatim \\
\hline Ida & $\begin{array}{l}\text { "My mother.... I do not know how to explain my relationship with her. I really cannot go along } \\
\text { with her" (Ida, HG, P1/10 October 2012: } 9.15 \text { a.m) }\end{array}$ \\
\hline Siti & $\begin{array}{l}\text { "My mother never thinks and cares about me. I am nobody to her. She is a slut.....slut and wild } \\
\text { like me. When I told her that I am pregnant and want to marry the boy (my boyfriend), she said it } \\
\text { is up to me to decide. It is not her call. She is not going to put any single cent for the wedding. } \\
\text { That is my and my grandmother's problem" (Siti, HG, P1/9 October 2012: } 10.15 \text { a.m) }\end{array}$ \\
\hline Aminah & $\begin{array}{l}\text { "I hardly talk with my mum and dad. I... actually, never talk to them" (Aminah, HG, P1/9 } \\
\text { October 2012: } 9.00 \text { a.m) }\end{array}$ \\
\hline Mira & $\begin{array}{l}\text { "He (father) does not love me. He never care about me" (Mira, HG, P1/9 October 2012: } 4.00 \\
\text { p.m) }\end{array}$ \\
\hline Jia & $\begin{array}{l}\text { "I do not know why I always quarrel with my mum.... I think because I cannot communicate } \\
\text { with her. She does not understand me" (Jia, TSP, P1/17 January 2013, } 11.29 \text { a.m) }\end{array}$ \\
\hline Eira & $\begin{array}{l}\text { "... I hate him (father). He only loves and care about his son, my brother. He is his biological } \\
\text { son. I am only his step-daughter. We don't look at each other. We also try to avoid each other. If } \\
\text { I know that he is coming back to the house, I will go into my room, lock myself in there" (Eira, } \\
\text { TSP, P1/( January } 2013,10.58 \mathrm{am})\end{array}$ \\
\hline Asma & $\begin{array}{l}\text { "Since I was a kid, I do not have a good relationship with my mother. I don't like her, and she } \\
\text { also doesn't like me. We always quarrel" (Asma, TSP, P1/17 February 2013, } 12.45 \text { p.m) }\end{array}$ \\
\hline Sha & $\begin{array}{l}\text { "I don't have good relation with my father because he always not around. My mum..... She does } \\
\text { not understand me. She likes to blame me in everything. So, I just keep quiet and keep } \\
\text { everything in my heart" (Sha, TSP, P1/17 March } 2013,10 \text { a.m) }\end{array}$ \\
\hline Bai & $\begin{array}{l}\text { "He (father) does a lot of problem....loves to fight with my mother. I love my mum. I hate my } \\
\text { father because he has another wife" (Bai, TSP, P1/7 September } 2012,8.37 \text { a.m) }\end{array}$ \\
\hline
\end{tabular}




\section{No conducive parenting}

Most parents of pregnant teens involved in this study were reported to practice the authoritarian parenting style. All of them expressed that their parents stringently control them, without sound justifications for the attitude. They also were forced to obey and abide by the house rules, without any space to question its reasonableness. Their parents also prefer to punish them with severe and painful physical and mental punishment. Never their parents negotiate with them.

Liberal parenting style that all-out give children right to decide about their lives also is very potential to facilitate child involvement in antisocial behaviour. Tehah's case provides the exclusive example. Her parents were so liberal towards her. The parents gave her so much freedom. They never interfere with Tehah activities and behaviour. As an outcome, Tehah was beyond control. She frequently absent herself from school hangs out at her boyfriend's house, freely involved with sex activities, wandering around towns, and associated with delinquent boys. Quote Tehah:

"I was wild.... I can do whatever I like.... My mum... I do not know what time she will be in the house. My father... he is busy with his work. They never ask about my daily activities. They never scold me if I did something wrong..... For example, if I don't want to go to school, or if I want to sleep over at my boyfriend's house... they did not say anything"

(Tehah, TSP, P1/7 January 2013, 11.40 a.m.)

\section{Incest, sexual abuse and violence in the family}

Two respondents reported that their biology fathers impregnate them. Ida, for instances, told us that her parents divorced when she was still a baby. She knew nothing about her father. Her mother also never told her about her father. She also admits that she loves to involve with adult men who has father-figure qualities. Then, she met one middle-aged man. The man lured her with all the loves and care. She 
loves the man. To prove her love and feelings toward him, she consensually had sex intercourse with the man. To her surprise, the man is her own father. She told us:

"My mother asked me who impregnated me. When I told her the man's name, she was surprised. Then, she told me that she want to meet the man. The man... he did not want to meet my mum. I showed my mum his photo. My mum shocked and cried......then, she told me that the man in the photo is my biological father"

(Ida, HG, P1/10 October 2012: 9.15 a.m)

Six of the respondent (50 per cent) told the researcher that their peers raped them. Sha, Tehah, Eira, Aya, Khai and Nur, however, did not blame the perpetrators. They, in fact, blamed themselves for trusting their peers. After the first incident of rape, their involvements with free unprotected and premature sex with various partners were frequent. They were so ignorant to think that if they were to be careful, they would not be pregnant. Unfortunately, they got pregnant, without even know who the father of their child was.

Domestic violence has a negative effect on adolescents' coping strategies. Few of the respondents explained that they did not like to stay in their homes because they were so depressed to witness their father's abusive behaviours towards their mothers. In the case of Eira, for instances, she told us that she hate her step-father because he is so abusive. He always quarrels and beat either Eira or her mother. Before her mother married to the step-father, the house was blissful. Her mother is the second wife. The father love to stay with the first wife and only visit the second wife once in a while. Quarrels occur during the visits, especially when Eira mother asked him for some money for the household necessities. Most of the time, the arguments become abusive. According to Eira, the step-father once tried to knock down her mother with his car.

"My mum married another woman husband. Each time when my stepfather comes back to the house, he will quarrel with my mum. Each time he comes, he will abuse my mum. He pushed her. He beat her. He even tried to hit my mum with his car"

(Eira, TSP, P1/9 January 2013, 10.55 a.m.) 
Eira could not tolerate with the situation. Her coping was to get out from the house and spend more time outside the home with her friends. She also loves to sleep over at her friends' houses; after attending parties where drugs and pills were distributed to her. The rape took place in one of the events.

Undoubtedly, findings from these two qualitative studies prove that a family ecology has an influential consequence on children sexual behaviour. Each of the family domain discussed in this paper integrate to influence negative sexual behaviour among teenagers. Teen girls are at the highest risk being involved with premature sex activities when the family domains are detrimental. In the next section, we propose an intervention that could response to the disadvantageous of the family ecology so that at-risk teens could be protective from premature sex activities and out of wedlock pregnancy.

\section{DISSCUSSION AND RECOMMENDATIONS}

The studies confirmed that a family ecology, in particular its internal domains (i.e., child-parents relationship, child-parents communication, parenting style, family structure, violence in the family, antisocial role-model etc.) are significant risk factors to influence teens girls involvement in premature sex activities and later get them pregnant out of wedlock. Thus, policies and intervention programmes or prevention measures for the social ill need to be planned centred on family, exclusively focused on parents-child participation. We proposed an intervention that is in line with the empirical evidences.

\section{Parent-based intervention programmes}

Prevention programmes that involve parents' participation are proven to be effective to response to the problem of premature sex and premature pregnancy among at-risk adolescents; as well as successful in delaying the adolescent involvement in premature sexual activities (Bouris et al., 2012; Guilamo-Ramos et al., 2011(b); Tanner et al., 2008; Forehand et al., 2007). 
Bouris et al., (2012) quoted Albert's evaluation report on National Campaign to Prevent Teenage Pregnancies in the States (2010). 55 per cent of 1008 American teens (12 to 19 years old) that participated in the campaign stated that their parents were the most influential person in their lives, especially in guiding and coaching them about sex and sexuality issues and realities. Their parents play an imperative role in assisting them to make decisions related to sex attitudes and behaviours. Parents-child communication about sex, parents attitudes and values about sex, parents guidance and control, act either as protective or stimulant factors to child involvement in premature sex activities and premature pregnancy.

Guilamo-Ramos et al., (2011a) discovered that parents are the primary source for emotional and instrumental support for teens. Thus, prevention programmes that involve active parents' participation reflects parents' interest, responsibilities and roles about their children lives and wellbeing. Strategies that promote active and conducive parenting are efficient to reduce teen's involvement in harmful sexual activities because parents are the primary socialization agent for a child sexual behaviour, and parents are also the key agent for child protection. Based on the rationalisation, intervention programmes that are family or parents- based, such as the Parents Matters, Families Talking Together, Families Unidas (United Families), and Take Care of Them (Cuidalos) are general. The programmes are implemented continuously in most advanced countries. To be precise, initiatives for teenage girl's premature pregnancy are more effective if parent's influences being benefited into programmes and policies related to child protection.

From the perspective of Family Social Work, intervention programmes that are parents-based or family-based are frequently referred to as Family Therapy or Multi-Family Group (MFG) Intervention Strategy. The development of the intervention is based on the Attachment Theory, and other theories related to the family system. It was also developed from hypothesis that viewed family therapy are capable of restoring family livelihood, which later are likely to reduce or prevent teenagers involvement in at-risk behaviour, in particular premature sex activities. The treatment includes a case management system and supportive counselling intervention, which are delivered in the family domain, or home sphere of the 
involved at-risk teens (McDonald et al., 2009). The therapy gives special attention to parents-adolescent child communication, parents-adolescent child caregiving role, and parents-adolescent child interaction patterns (Chemiss, 1966).

Any prevention programmes that are family or parents-based, in particular intervention that is based on family therapy strategy, parental components in the therapy need to be clearly specified. In order to assist the parents to facilitate their children to a constructive sexual attitude, values and behaviours, the structure of the programme need to be explicit. Important aspects that should be included in the components of the programme are ( Guilamo-Ramos et al., 2011a; Guilamo-Ramos et al., 2011b; Jaccard, 2009: Tanner et al., 2008; Forehand et al., 2007; GuilamoRamos, Jaccard \& Casillas, 2004):

1) Parents awareness about adolescent risk sex behaviour,

2) Sexual communication between parents and adolescent,

3) Effective communication strategies between parents-child, that includes parents-adolescent communication about sex behaviour and model of communication behavioural for parents,

4) Creative and effective parenting strategies that focus on skills that likely to reduce adolescent involvement in risky sex behaviours,

5) Effective parental monitoring strategies to supervise child daily activities,

6) Critical thinking strategies and effective problem-solving for parents,

7) Maternal monitoring and supervision that focus on interaction and communication relationship about positive sexual behaviour model, transmission of information and positive perception about sex and sexuality behaviour,

8) Cultural values, religion/faith and sex behaviour; and,

9) Positive message and knowledge about reproductive health.

In addition to that, parents-based intervention programmes to prevent teenage premature pregnancy should be idealistic. Based on their evaluation on the Parents Matter! and few others intervention programmes in the U.S.A; Guilamo-Ramos and Casillas (2004) had identified four extra ideal characteristics that should be included in the parents-based intervention programmes to prevent involvement in premature sex and premature pregnancy among teenagers. The first characteristic is the 
programme should be explicit, practical and cost-effective. The intervention should be able to change the risk behaviour. The behavioural change intervention should also be carried out in an intensive and continuous manner; not once in a while and just "touch and go". The second aspect is the intervention should be accessible to all at-risk adolescents, in particular to the highest risk group, with consideration to issues of cultural heterogeneous, values and social needs of the adolescents. The third characteristic is the programme involves a partnership from all sectors in the community, such as school, housing associations, faith-based organisations, and neighbourhood. The last perfect characteristic is the intervention must be effective. A programme's effectiveness can be measured through its integrity or transparency in utilising latest strategies to change risk behaviours among adolescents, theorybased, community-based, perceptive to adolescent needs, and sustainable.

\section{CONCLUSION}

The goal of the studies was to explore the relationship between family ecology and adolescent premature pregnancy, in Malaysia. The findings confirmed that six family domains; family social-demography, parenting style, parents' control and monitoring of their children's behaviour and activities, parent-child communication, parental support and family structure have significant influence on adolescents' involvement in sexual misconducts, which later contribute to their out of wedlock pregnancy. As a recommendation, this paper suggests a family-based intervention model. To be efficient, all sectors in the community, such as the informal (i.e., the family, neighbourhood), formal sector (i.e., the school, social welfare agencies and other human services agencies, PTA), the private sector (i.e., business and corporate), and the third sector (i.e., self-help groups, voluntary organizations, NGOs) need to work in a partnership manner in providing conducive social facilities and pro-social activities to safeguard children in the community. We can control the problem if members of society can come up with this kind of intervention. 


\section{REFERENCES}

Albert, B. (2010). With one voice: America's adults and teens sound off about teen pregnancy. Washington, DC: National Campaign to Prevent Teen and Unplanned Pregnancy.

Ballantine, J. (2001). Raising competent kids: the authoritative parenting style. Childhood Education, 78, 46-47.

Benson, M. J. (2004). After the adolescent pregnancy: parents, teens and families. Child and Adolescent Social Work Journal, 21(5), 435-455.

Blake, B. J., \& Bentov, L. (2001). Geographical mapping of unmarried teen births and selected sociodemographic variables. Public Health Nursing, 18, 33-39.

Bouris, A., Guilamo-Ramos,V., Cherry, K., Dittus, P., Michael, S., \& Gloppen, K. (2012). Preventing rapid repeat births among Latina adolescents: The role of parents. American Journal of Public Health, 102(10), 1842-1849.

Bronfenbrenner, U. (1986). Ecology of the family as a context for human development: Research perspectives. Developmental Psychology, 22, 723-742.

Burns, V. E. (2008). Living without a strong father figure: A context for teen mothers' experience of having become sexually active. Issues in Mental Health Nursing, 29, 279-297.

Cervera, N. (1994). Family change during an unwed teenage pregnancy. Journal of Youth and Adolescence, 23(1), 119-140.

Chemiss, C. H. (1996). Impact of home-based family therapy on maternal and child outcomes in disadvantaged adolescent mothers. Family Relations, 45(1), 72-79.

Coleman, L. M. (2004). New opportunities for reducing the risk from teenage pregnancy - what is the evidence base for tackling risk behaviours in combination?. Health, Risk \& Society, 4(1), 77- 93.

Commendador, K. (2011). The relationship between maternal parenting style, female adolescent decision making, and contraceptive use. Journal of the American Academy of Nurse Practitioners, 23, 561-572.

Davis, E. C., \& Friel, L.V. (2001). Adolescent sexuality: Disentangling the effects of family structure and family context. Journal of Marriage and Family, 63, 669681.

Dilorio, C., McCarty, F., Denzmore, P., \& Landis, A. (2007). The moderating influences of mother-adolescent discussion on early and middle African American adolescent sexual behavior. Research in Nursing Health, 30, 193202. 
Doshi-Gandhi, A. (2013). Cabaran transformatif masyarakat sejahtera. In Roziah Omar, Sivamurugan Pandian \& Zainal Abidin Sanusi (pnytg). Prosiding Konvensyen Kebangsaan Kepimpinan IPT dan Kesejahteraan Sosial: Merealisasikan transformasi ke arah masyarakat sejahtera (pp. 55-63). Malasyia: AKEPT, KPT.

Eisenberg, M. E., Sieving, R. E., Bearinger, L. H., Swain, C., \& Resnick, M. D. (2006). Parent communication with adolescents about sexual behavior: A missed opportunity for prevention?. Journal of Youth and Adolescence, 35, 893-902.

Finkelhor, D., Ormrod, R., \& Turner, H. (2007). Re-victimization patterns in a national longitudinal sample of children and youth. Child Abuse and Neglect, 31, 479-502.

Forehand, R., Armistead, L., Long, N., Wyckoff, S. C., Kotchick, B. A., Whitaker, D., Shaffer, A., Greenberg, A. E., Murry, V., Jackson, L. C., Kelly, A., McNair, L., Dittuus, P. J., Lin, C. Y., \& Kim, S. M. (2007). Efficacy of a parent-based sexual-risk prevention program for African American preadolescents. A randomized controlled trial. Arch Pediatric Adolescence Med., 161(12), 1123-1129.

Francisco, M. A., Hicks, K., Powell, J., Styles, K., Tabor, J. L., \& Hulton, L. J. (2007). The effect of childhood sexual abuse on adolescent pregnancy: An integrative research review. Journal for Specialists in Pediatric Nursing, 13(4), 237-248.

Fisher, T. D. (1989). An extension of the findings of Moore, Peterson, and Furstenberg (1986) regarding family sexual communication and adolescent sexual behavior. Journal of Marriage and the Family, 51, 637-639.

Gordon, C. P. (1996). Adolescent decision making: a broadly based theory and its application to the prevention of early pregnancy. Adolescence, 31, 576-584.

Guilamo-Ramos, V., Bouris, A., Jaccard, J., Lesesne, C., \& Ballan, M. (2009). Familial and cultural influences on sexual risk behaviors among Mexican, Puerto Rican, and Dominican youth. AIDS Educational Preview, 21(5), 61-79.

Guilamo-Ramos, V., Jaccard, J., \& Casillas, E. (2004). The Parents Matter! Program: Practical, Theoretical, and Methodological Perspectives. Journal of Children and Family Studies, 13(1), 113-123.

Guilamo-Ramos,V., Jaccard, J., \& Dittus, P. (2011a). A parent-based intervention to reduce sexual risk behavior in early adolescence: building alliances between physicians, social workers, and parents. Journal of Adolescence Health, 48(2), 159-163. 
Guilamo-Ramos, V, Jaccard, J., Dittus, P. Bouris, A., Gonzales, B., Casillas, E., \& Banspach, S. (2011b). A comparative study of interventions for delaying the initiation of sexual intercourse among Latino and Black youth. Perspective of Sexual and Reproductive Health, 43(4), 247-254.

Guilamo-Ramos, V., Jaccard, J., Dittus, P., \& Collins, S. (2008). Parent-adolescent communication about sexual intercourse: An analysis of maternal reluctant to communicate. Health Psychology, 27, 760-769.

Guilamo- Ramos, V., Jaccard, J., \& Casillas, E. (2004). The Parents Matter! program: practical, theoretical, and methodological perspectives. Journal of Children and Family Studies, 13(1), 113-123.

Hoga, L. A. K, Borges, A. L. V., \& Alvarez, R. E. C. (2009). Teen pregnancy: values and reactions of family members. Acta Paul Enfem, 22(6), 779-85.

Hogan, D., \& Kitagawa, E. (1995). The impact of social status, family structure, and neighborhood on the fertility of black adolescents. Adolescence, 90, 825-836.

Hutchinson, M. K., Waldron, N., Hewitt, H. H., \& Alter, E. (2012). Jamaican mothers' influences of adolescent girls' sexual beliefs and behaviors. Journal of Nursing Scholarship, 44(1), 27-35.

Hutchinson, M. K., \& Cederbaum, J. (2011). Talking to daddy's little girl about sex: Daughters' reports of sexual communication and support from fathers. Journal of Family Issues, 32, 550-572.

Hutchinson, M. K., \& Montgomery, A. (2007). Parent communication and sexual risk among African Americans. Western Journal of Nursing Research, 29, 691707.

Jaccard, J. (2009). Unlocking the contraceptive conundrum: Reducing unplanned pregnancies in emerging adulthood. Washington, DC: National Campaign to Prevent Teen and Unplanned Pregnancy.

Jaccard, J., Dodge, T., \& Dittus, P. (2002). Parent-adolescent communication about sex and birth control: a conceptual framework. In Feldman, S. S., \& Rosenthal, D. A. (Eds.). Talking sexuality: Parental-Adolescent Communication. San Francisco, CA: Jossey-Bass.

Katerndahl, D., Burge, S., Kellogg, N., \& Parra, J. (2005). Differences in childhood sexual abuse experience between adult Hispanic and Anglo women in a primary care setting. Journal of Child Sexual Abuse, 14(2), 85-95.

Malaysia (2001). Child Act 2001 (Act 611). Kuala Lumpur: International Law Book Services. 
Lickona, T. (1998). Sex education for the neglected heart. Reclaiming Children and Youth, 7(1), 9-17.

Lipovsek, V., Karim, A. M., Gutierez, E. Z., Magnani, R. J., \& Gomez, M. C. C. (2000). Risk and protective factors for unplanned pregnancy among adolescents in Bolivia. Washington, DC: Focus on young adults/ Pathfinder International.

Lloyd, S. L. (2004). Pregnant adolescent reflections of parental communication. Journal of Community Health Nursing, 21(4), 239-251.

Lovett, B. B. (2004). Child sexual abuse disclosure: maternal response and other variables impacting the victim. Child and Adolescent Social Work Journal, 21(4), 335-371.

Martin, E. K., Campbell, C., \& Hersen, D. J. (2010). Child sexual abuse. In J. C. Thomas \& M. Hersen (Eds.), Handbook of clinical psychology competencies, volume III: Intervention and treatment for children and adolescents (pp. 14811514). New York: Springer.

McDonald, L., Conrad, T., Fairtlough, A., Fletcher, J., Green, L., Moore, L., \& Lepps, B. (2009). An evaluation of a groupwork intervention for teenage mothers and their families. Child \& Family Social Work, 14, 45-57.

Miller, B. C. (2002). Family influences on adolescent sexual and contraceptive behavior. Journal of Sex Research, 39(1), 22-27.

Miller, B. C., Benson, B., \& Galbraith, K. A. (2001). Family relationships and adolescent pregnancy risk: A research synthesis. Developmental Review, 21, 138 .

Nash, S., McQueen, A., \& Bray, J. H. (2005). Pathways to adolescent alcohol use: Family environment, peer influence, and parental expectations. Journal of Teen Health, 37, 19-28.

Pereira, A, I., Canavarro, M. C., Cardoso, M. F., \& Mendonca, D. (2005). Relational factors of vulnerability and protection for adolescent pregnancy: A crosssectional comparative study of Portuguese pregnant and non-pregnant adolescents of low socioeconomic status. Adolescence, 40(159), 655-671.

Quinlivan, J. A., Tan, L, H., Steele, A., \& Black, K. (2004). Impact of demographic factors, early family relationships and depressive symptomatology in teenage pregnancy. Australian and New Zealand Journal of Psychiatry, 38, 197-203.

Quinlivan, J. A., \& Evans, S. F. (2001). The impact of domestic violence in teenage pregnancy - a prospective cohort study. Journal of Pediatric and Adolescent Gynecology, 14, 17-23. 
Roberts, S. R., Lewis, R. K., \& Carmack, C. (2011). Positive youth development among African American adolescents: Examining single parents as a factor. Journal of Prevention and Intervention in the Community, 39, 310-319.

Saewyc, E. M., MGee, L. L., \& Pettingell, S. E. (2004). Teenage pregnancy and associated risk behaviors among sexually abused adolescents. Perspectives on Sexual Abuse and Reproductive Health, 36(3), 98-105.

Singh, S., Darroch, J. E., \& Frost, J. J. (2001). Socioeconomic disadvantage and adolescent women's sexual and reproductive behaviour: the case of five developed countries. Family Planning Perspectives, 33, 251-258.

Siti Hajar Abu Bakar \& Abd. Hadi Zakaria. (2009). Perlindungan kanak-kanak berisiko. Kuala Lumpur: Penerbit Universiti Malaya.

Social Welfare Department of Malaysia. (2010). Pregnancy among girls. Unpublished report. Kuala Lumpur: Social Welfare Department.

Staton, B., Cole, M., Galbraith, J., Li, X., Pendleton, S, Cottrel, L., Marshall, S., Wu, Y., \& Kaljee, L. (2004). Randomized trial of a parent intervention. Parents can make a difference in long-term adolescent risk behaviors, perceptions and knowledge. Arch Pediatric Adolescence Medical, 158, 947-955.

Steel, J., \& Herlitz, C. (2005). The association between childhood and adolescent sexual abuse for proxies for sexual risk behavior: A random sample of the general population of Sweden. Child Abuse and Neglect, 29, 1141-1153.

Sturgeon, S.W. (2008). The relationship between family structure and adolescent sexual activity. Washington, DC: The Heritage Foundation.

Tanner, J. F., Carlson, L. A., Raymond, M. A., \& Hopkins, C.D. (2008). Reaching parents to prevent adolescent risky behavior: Examining the effects of threat portrayal and parenting orientation on parental participation perceptions. Journal of Public Policy and Marketing, 27(2), 149-155.

Taris, T. W., \& Semin, G. R. (1998). How mothers' parenting styles affect their children sexual efficacy and experience. J Genet Psychol, 59, 68-81.

Tomall, A. (1999). Determinants of teenage birth rates as an unpooled sample: age matters for socio-economics predictors. The American Journal of Economic and Sociology, 58, 57-69.

Tyler, K. A., \& Cauce, A. M. (2002). Perpetrators of early physical and sexual abuse among homeless and runaway adolescents. Child Abuse and Neglect, 26, 1261-1274.

Tucker, C., Perreira, K., \& Halpern, C.T. (2011, March-April). Parenting strategies and teenage pregnancy. Paper presented at the Population Association of America 2011 Annual Meeting Program. Marriot Wardman Park: Washington, DC. 
Velez-Pastrana, M. C., Gonzalez-Rodriguez, R. A., \& Borges-Hernandez, A. (2005). Family functioning and early onset of sexual intercourse in Latino adolescents. Adolescences, 40(160), 777-791.

Walker, E. C., Holman, T. B., \& Busby, D. M. (2009). Childhood sexual abuse, other childhood factors, and pathways to survivors' adult relationship quality. Journal of Family Violence 24, 397-406.

Wellings, K., Wadsworth, J., Johnson, A., Field, J., \& Macdowall, W. (1999). Teenage fertility and life chances. Reviews of Reproduction, 4, 184-190.

Williams, C., \& Vinnes, S. W. (1999). Broken past, fragile future: personal stories of high risk adolescent mothers. Journal of the Society of Pediatric Nurses, 4, 1523.

Wilson, D. R. (2009). Health consequences of childhood sexual abuse. Perspective in Psychiatric Care, 46(1), 56-64.

Wilson, E. K., Dalberth, B. T., Koo, H. P., \& Gard, J. C. (2010). Parents' perspectives on talking to preteenage children about sex. Perspectives on Sexual and Reproductive Health, 42(1), 56-63.

Woodward, L., Fergusson, D. M., \& Horwood, L. J. (2001). Risk factors and life processes associated with teenage pregnancy: Results of a prospective study from birth to 20 years. Journal of Marriage and the Family, 63, 1170-1185.

Yampolskaya, S., Brown, E. C., \& Greenbaum, P. E. (2002). Early pregnancy among adolescent females with serious emotional disturbances: Risk factors and outcomes. Journals of Educational and Behavioral Disorders, 10, 108-126.

Young, T., Turner, J., Denny, G., \& Young, M. (2004). Examining external and internal poverty as antecedents of teen pregnancy. American Journal of Health Behavior, 28(4), 361-373.

Young, E. W., Jensen, L. C., Olsen, J. A., \& Cundick, B. P. (1991). The effects of family structure on the sexual behavior of adolescents. Adolescence, 26(104), 977-986. 